\title{
Corporate Governance and Bank Performance: A Study of Selected Banks in GCC Region
}

\author{
Mohammad Naushad ${ }^{1} \&$ Syed Abdul Malik ${ }^{1}$ \\ ${ }^{1}$ College of Business Administration, Salman bin Abdulaziz University, Al-Kharj, Kingdom of Saudi Arabia \\ (KSA) \\ Correspondence: Mohammad Nausahd, College of Business Administration, Salman bin Abdulaziz University, P. \\ O. Box-165, Al-Kharj- 11942, Kingdom of Saudi Arabia (KSA). Tel: 966-11-588-7065; 966-56-690-2583. \\ E-mail: n.mohammad@sau.edu.sa; meetnaushad@gmail.com
}

Received: October 31, 2014 Accepted: December 4, $2014 \quad$ Online Published: April 2, 2015

doi:10.5539/ass.v11n9p226

URL: http://dx.doi.org/10.5539/ass.v11n9p226

\begin{abstract}
This paper examines the effect of corporate governance denoted by board size, duality, agency cost etc. on the performance of selected 24 GCC banks based on the criteria of total assets for the financial year 2012-13. Tobin's Q and Return on Total Assets (ROTA) are adopted as a measurement of accounting and financial performance respectively.

The results indicate that smaller boards are more capable for monitoring the management closely in GCC banking sector. Dual role of Chief Executive Officer (CEO) are likely to improve the GCC bank performance. The presence of block holders in ownership structure of GCC banks tends to have a positive effect on the performance of banking sector. Overall, the study concludes that the corporate governance poses a significant influence on the financial and accounting performance of GCC banking sector.
\end{abstract}

Keywords: corporate governance, bank performance, Tobin's Q, ROTA, GCC Banks

\section{Introduction}

Agency problem is not new to the corporates. Primarily, it resulted from the split-up of ownership from management. It upshot in Managements' lower interest (Jensen \& Meckling, 1976). Researchers conclude that firms with greater agency problem performed poorly. Thus, an efficient governance structure proved effective in alleviation of such giant problem (the agency problem) (Brown \& Caylor, 2004) and ultimate resulting in the better performance. Most noteworthy are a good number of researches e.g., (Bhagat \& Bolton, 2008; Fallatah \& Dickins, 2012; Grove, Patelli, Victoravich, \& Xu, 2011; Kapopoulos \& Lazaretou, 2007), Al-Rashed (2010); Shleifer and Vishny (1997); Hermalin and Weisbach (1991) etc. that proved the fact stated above.

The global financial crisis of 2007 has again fierce the debate over the relationship of corporate governance and the performance of firms specifically banks. Despite its importance, this topic has been explored only by a few studies. But very few are in the bank perspectives and a few are for the GCC.

This study is an outcome of research conducted to portray the effect of different aspects (variables) of corporate governance on bank performance. The focus area for the study covers the leading banks in the GCC region.

\section{Literature Review}

The literature on how the corporate governance does influence the firm performance is widespread though the outcomes are contrary. Larcker, Richardson, and Tuna (2007) for example, determine that the relationship of corporate governance and performance of firms fail to produce a consistent set of results. Fallatah and Dickins (2012), concluded that corporate governance and firm performance (measured as return on assets) are unrelated, but corporate governance and value of firm (as measured by Tobin's Q and market value of equity) are positively related. Barako and Tower (2007), found foreign and government ownership in board are negatively related with firm performance. Similarly, Heracleous (2001) conducted a research on the theme and concluded, "researches have failed to find any convincing connection between the best practices in corporate governance and organizational performance". He concluded that best practices of corporate governance like CEO/Chair duality and insider/outsider composition and organizational performance are insignificantly related. In contrast, Tandelilin, Kaaro, and Mahadwartha (2007) cited a positive relationship with no liner effect among corporate 
governance and firm performance. Additionally, Brown and Caylor (2004), concluded that "firms with weaker governance perform more poorly, are less profitable, more risky, and have lower dividends than firms with better governance". Authors found a strong correlation between corporate governance and firm performance for a large sample of US firms. Similarly, Kapopoulos and Lazaretou (2007) cited a linear positive relationship between profitability and ownership structure.

\subsection{Corporate Governance and Bank Performance}

The aforementioned studies witnessed that corporate governance and firm performance is well taken by the researchers render mixed results. But the focus of the present study is to trace out the relationship between the corporate governance and the bank performance. Banks are among the most important sources not only of finance but also of external governance for firms. Unlike, other corporations banks carry a special responsibility to take care of people's money as well as maintain trust among the other stakeholders. Therefore, banks need to be more accountable and transparent. Thus, the structure of the governance of banks remains unique in nature.

Some studies focuses on the performance of GCC banks follows specifically, Al-Musalli and Ismail (2012) investigated the upshots of corporate governance variables on Intellectual Capital Performance (ICP). Researchers concluded that there is no effect of bank size on its performance. While, intellectual capital performance and bank financial performance is positively related. Arouri, Hossain, and Muttakin (2011) examined the linkages of bank performance (ROA) and Board Size, CEO Duality, Block holders, Institutional Ownership and Foreign ownership for 27 banks from GCC countries except Kuwait from 2008 (Table 1). The authors found foreign ownership and bank performance are significantly associated while the ownership is to be found negatively associated with performance. On the other hand the board characteristics like board-size and duality insignificantly impact the performance. And the size of the bank affects performance positively.

Some other studies have also examined the relationship and impact of corporate governance on banking industry-see for example, Sufian (2010), Kabigting (2011) and Grove et al. (2011) etc. Grove et al. (2011) carried out a study on 236 US public commercial banks from 2005-2008 to find out the corporate governance impact on the bank performance. Authors classified the corporate governance variables in two categories, i.e. governance factors and control variables. The findings of the study suggest that board size and financial performance is negatively associated while insider representation is positively related with performance. Moreover the dual role of CEO has a negative association with financial performance. Table 1 portrays a summarized picture of various studies conducted on corporate governance and firm performance.

Table 1. A comparison of corporate governance factors and firm performance in some illustrative studies

\begin{tabular}{|c|c|c|c|}
\hline Study & Sample & Variables Tested & Results \\
\hline $\begin{array}{l}\text { Al-Musalli } \\
\text { and Ismail } \\
(2012)\end{array}$ & $\begin{array}{l}74 \text { listed } \\
\text { banks of } \\
\text { GCC } \\
\text { during the } \\
\text { period } \\
2008-2010 \\
\text { except } \\
\text { Kuwaiti } \\
\text { listed } \\
\text { banks (11 } \\
\text { banks). }\end{array}$ & $\begin{array}{l}\text { Dependent: Intellectual Capital } \\
\text { Performance (ICP) } \\
\text { Independent: Adherence to Islamic Sharia } \\
\text { principles, Bank internationality, Bank } \\
\text { riskiness, Bank size, Banking industry } \\
\text { concentration, Board independence, Board } \\
\text { size, Domestic strategic institutional } \\
\text { ownership, Family ownership, Foreign } \\
\text { strategic institutional ownership, } \\
\text { Governmental ownership, Presence of } \\
\text { foreign banks and Return on equity. }\end{array}$ & $\begin{array}{l}\text { - There is a positive significant relationship } \\
\text { between bank financial performance and ICP } \\
\text { and a moderate negative relationship between } \\
\text { domestic strategic institutional ownership and } \\
\text { ICP. } \\
\text { - Bank size does not affect bank performance. } \\
\text { - Board size, presence of independent directors } \\
\text { and ICP are negatively associated. } \\
\text { - Family ownership has a negative effect with } \\
\text { ICP. } \\
\text { - Foreign banks and other FIIs do not improve } \\
\text { ICP of GCC banks }\end{array}$ \\
\hline $\begin{array}{l}\text { Arouri et al. } \\
\qquad(2011)\end{array}$ & $\begin{array}{l}27 \text { banks } \\
\text { from GCC } \\
\text { countries } \\
\text { except } \\
\text { Kuwait } \\
\text { from } 2008\end{array}$ & $\begin{array}{l}\text { Dependent: Return on Assets (ROA } \\
\text { Independent: Block holders, Board Size, } \\
\text { CEO Duality, Foreign ownership and } \\
\text { Institutional Ownership }\end{array}$ & $\begin{array}{l}\text { - Board characteristics such as board size and } \\
\text { CEO duality do not have a significant impact } \\
\text { on performance. } \\
\text { - Firm performance and foreign ownership are } \\
\text { positively associated. } \\
\text { - Institutional ownership is negatively } \\
\text { associated with performance. } \\
\text { - The size of the bank affects positively on } \\
\text { performance }\end{array}$ \\
\hline $\begin{array}{c}\text { Kabigting } \\
\text { (2011) }\end{array}$ & $\begin{array}{l}\text { Listed } \\
\text { Banks of } \\
\text { Philippine } \\
\text { Stock } \\
\text { Exchange } \\
\text { (PSE) from }\end{array}$ & $\begin{array}{l}\text { Dependent Corporate Governance } \\
\text { (proxied by Insider Ownership), Corporate } \\
\text { Governance (proxied by board size) }\end{array}$ & $\begin{array}{l}\text { - Insider ownership has nothing to do with bank } \\
\text { age. } \\
\text { - Earnings per share and insider ownership are } \\
\text { negatively related. } \\
\text { - ROE and EPS are negatively related to board } \\
\text { size. }\end{array}$ \\
\hline
\end{tabular}




\begin{tabular}{|c|c|c|c|}
\hline Study & Sample & Variables Tested & Results \\
\hline & $\begin{array}{l}2005 \text { to } \\
2009 .\end{array}$ & $\begin{array}{l}\text { Non-performing loan (NPL), Return on } \\
\text { assets (ROA) and Return on equity (ROE) }\end{array}$ & $\begin{array}{l}\text { - corporate governance as proxied by insider } \\
\text { ownership has significant relationship with } \\
\text { ROA, bank size and EPS. Both bank size and } \\
\text { ROA are positively related while EPS is } \\
\text { negatively related to corporate governance. } \\
\text { - corporate governance as proxied by board } \\
\text { size has significant relationship with } \\
\text { independent board, EPS, ROA and ROE. } \\
\text { - Both independent board and ROA are } \\
\text { positively related while EPS and ROE are } \\
\text { negatively related to corporate governance. }\end{array}$ \\
\hline $\begin{array}{l}\text { Grove et al. } \\
\quad(2011)\end{array}$ & $\begin{array}{l}236 \text { US } \\
\text { public } \\
\text { commercia } \\
1 \text { banks } \\
\text { from } \\
2005-2008\end{array}$ & $\begin{array}{l}\text { Dependent: Bank performance proxies } \\
\text { denoted by Return on Assets, stock-alpha: } \\
\text { the measurement of future access return of } \\
\text { stocks, and the NPA ratio. } \\
\text { Independent: Various governance factors } \\
\text { along with two control variables }\end{array}$ & $\begin{array}{l}\text { - The performances of Banks with smaller } \\
\text { boards are found better in the later crises } \\
\text { duration. } \\
\text { - Block holder and bank performance have } \\
\text { negative and significant association in } \\
\text { between during the financial crisis. } \\
\text { - The duality of CEO plays a negative role in } \\
\text { financial performance. }\end{array}$ \\
\hline Sufian (2010) & $\begin{array}{l}\text { Islamic } \\
\text { Banks of } \\
\text { Malaysia } \\
\text { from } \\
\text { 2001-2007. }\end{array}$ & $\begin{array}{l}\text { Dependent: The return on total assets } \\
\text { (ROTA) of the banks during the year taken. } \\
\text { Independent: Variables were classified as } \\
\text { inside and outside the firm. The inside } \\
\text { variables include (1) size of bank (2) credit } \\
\text { risk (3) efficiency of management (4) } \\
\text { network embeddedness (5) bank's capital } \\
\text { strength. While, The outside variables } \\
\text { include (1) economic conditions (2) } \\
\text { inflation rate (3) bank ownership (4) period. }\end{array}$ & $\begin{array}{l}\text { The overhead cost is negatively related to } \\
\text { Malaysian Islamic banks' profitability. }\end{array}$ \\
\hline $\begin{array}{l}\text { Al-Rashed } \\
\text { (2010) }\end{array}$ & $\begin{array}{l}\text { Stock } \\
\text { exchanges } \\
\text { published } \\
\text { data } \\
\text { range from } \\
2007 \text { to } \\
2009\end{array}$ & $\begin{array}{l}\text { Dependent: Reported Earnings, Financial } \\
\text { Leverage, Cash Distributions, Share Price } \\
\text { and Management remunerations } \\
\text { Independent: General Assembly, Board of } \\
\text { Directors, Audit Committee, External } \\
\text { Auditor, Government Representatives, } \\
\text { Debtors and General Stakeholders }\end{array}$ & $\begin{array}{l}\text { Some correlation is found among factors } \\
\text { affecting corporate governance at the large scale } \\
\text { with variables that are usually linked to } \\
\text { corporate performance. }\end{array}$ \\
\hline $\begin{array}{l}\text { Kapopoulos } \\
\text { and Lazaretou } \\
\text { (2007) }\end{array}$ & $\begin{array}{l}175 \text { Greek } \\
\text { Firms from } \\
\text { year } 2000\end{array}$ & $\begin{array}{l}\text { Dependent: Firm Performance } \\
\text { Independent: corporate ownership } \\
\text { structure }\end{array}$ & $\begin{array}{l}\text { A linear positive relationship between } \\
\text { profitability and ownership structure. }\end{array}$ \\
\hline
\end{tabular}

\section{Methodology}

Up till now corporate governance among GCC countries is infantile state of affairs. The last decade only witnessed the emergence of corporate governance and the Arabic word 'HAWKAMAH' promulgated for corporate governance. But despite the infantile state and several challenges ahead in the region, corporate governance is making a mark in GCC (Saidi, 2011). Oman took the lead in the region to issue firstly a code of corporate governance in 2002. While on the other hand Kuwait left behind and could only incorporate certain guidelines in their company laws in 2012 still the governance code is yet to be finalized.

But despite of several initiatives and formal code of corporate governance existed in each country. Still there is a leap gap to align with the international corporate governance best practices and a dire need to strengthen more the structure so that the region could be safeguarded from the effects of any world economic turmoil.

The GCC banking sector except Bahrain and Oman was in totality conservative of nature earlier. It resulted in the entry restrictions for foreign banks. However a noticeable reversal can be seen in these policies specifically in last decade ( $\mathrm{Al}$ Karasneh \& Bolbol, 2006). But the corporate governance is introduced to banking sector along with other sectors only. The GCC banking sector has some special features such as family business ownership, existence of conventional and Islamic banks together. With the existence of many Islamic banks the GCC banking sector witnesses several unique characteristics. Though, the GCC governance codes do not address separately the Islamic banks except few provisions in the existing codes of governance.

In order to achieve the objectives of present study, 24 GCC banks are selected based on the criteria of total assets. Mainly data is collected from gulf base website (www.gulfbase.com) and cross verified with the annual reports, respective central banks of GCC countries and individual banks' websites. 


\subsection{Variable Selection and Hypothesis Development}

\subsubsection{Value of Firm /Bank Performance Variables}

Performance measurement of banks is getting complex more and more. The most common measurement for bank performance adopted by researchers is Return on Assets (ROA), see e.g. Arouri et al. (2011), Grove et al. (2011) and Sufian (2010) etc. refer also table 1. But as pointed out Larcker et al. (2007) \& Grove et al. (2011) $R O A$ is widely used as the measurement of accounting performance of firms. Generally, it gives an idea about how effectively $\&$ efficiently does a firm/bank utilize its resources to generate a good return. Therefore, our first independent variable to measure the bank performance is ROA/ROTA (Return on Total Assets).

The second performance measure, we use in the present study by considering the financial aspect. The TOBIN's $Q$ is denoted as the proxy for it. TOBIN's Q propounded by James C. Tobin (1969) explains the relationship of current cost of replacement assets to the market value of the firm's assets including share \& stocks (Al-Hawary).

Henceforth our study regress the twofold factors such as corporate governance factors and value of firms (CGVF) as advocated by Rashid and Islam (2013). Thus, we state the primary hypothesis of the study as below.

$\boldsymbol{H}_{1}=$ GCC bank performance is significantly influenced by the corporate governance factors.

The corporate governance factors considered in the present study is stated in the given next section.

\subsubsection{Corporate Governance Variables}

\subsubsection{Board Size}

The importance of board size to influence the performance/value of the firms is widely advocated by researchers see e.g., Grove et al. (2011), Kapopoulos and Lazaretou (2007), Dalton and Dalton (2005), etc. Researchers argued that larger board size with the blend of their educational background, talent, technical knowledge and skills etc. is more expected to draw the diverse talent and diversity to the board decisions Abeysekera (2010), Coles, Daniel, and Naveen (2008) and Dalton and Dalton (2005) etc. In contrast, Nam, Nam, and ong (2004), Beasley (1996), Jensen (1993) etc. argued that a lager board size usually lack effective communications causing dearth of open interface and arguments resulting in increasing the CEOs power. Thus in this light our second hypothesis state below.

$\boldsymbol{H}_{2}=$ Board size positively affect the value/performance of GCC banks.

\subsubsection{Duality}

Early studies like, Jensen and Meckling (1976) and Cadbury committee report see Cadbury (1992) it-self argued that the position of CEO and the Board chairman should not be hold by one person only. As it reduces the degree of independency of board in one hand and widen the area of self-serving and entrenchment for CEO on other hand (Kang \& Zardkoohi, 2005). In continuance to the preceding trend we also purpose,

$\boldsymbol{H}_{3}=$ CEO Duality has a negative effect on the performance of GCC Banks.

\subsubsection{Block Ownership}

GCC banking sector has a unique characteristics in terms of ownership structure as large size of ownership concentration is based on either family ownership or other block holders (Chahine, 2007). The presence of block holders in the firm's ownership were assumed to facilitate better monitoring inducements leading to great performance (Leech \& Leahy, 1991). Researchers such as Ongore (2011), Hartzell and Starks (2003) and Smith (1996) suggest that manager behavior can be constrained by the corporate monitoring done by the institutional investors/ block holders. Our approach also supports the earlier studies as well, so the hypothesis to test it can be:

$\boldsymbol{H}_{4}=$ Block holders in the ownership structure of GCC banks positively influence the performance.

\subsubsection{Control Variables}

The organizational characteristics of each firm do have an influence on the structure of corporate governance followed that upshot into the impact on performance (Grove, 2011). Therefore in the regression model to nullify this effect the control variables are useful. As per www.businesdictionary.com, "control variable is the variable that is held constant in order to assess or clarify the relationship between two other variables". Thus two variables i.e. total assets and market capitalization has been constructed as the control variable. In order to purge the multi-collinearity effect natural logs of the variables are taken.

\subsection{Model Specification}

As specified in the above section, we have selected two dependent variables represented by ROA and Tobin's $Q$. The Corporate Governance variables specifically include the board size, duality, block ownership and agency 
cost. The value of $R O A$ is get after dividing the operating income by total assets for each bank. While TOBIN's $Q$ is considered the proxy for financial performance calculated on the basis of formulation given in (investopedia.com), i.e.

$$
\text { TOBIN's } \mathbf{Q}=\frac{\text { Total Market Value of the Firm }}{\text { Total Assets Value }}
$$

First independent corporate governance variable is the board size of banks. The variable is measured by summing up the total number of board members inclusive of chairman, vice-chairman and CEO. The next independent variable is Duality. It is a dummy variable. The variable is constructed to test the influence of leadership structure on overall value of the GCC banks. It is considered 1, where CEO and Chairman is the same person, otherwise $=0$. Block Ownership represents the sum of majority shareholders. It is get by summing up the percentage of ownership holds by all majority shareholders. The majority shareholder we have considered to those who holds 5 or more percent of shares. Ownership structure is also a measure for agency cost. Instead of taking the dummy variable we have add all the majority shareholders percentage to get the Agency Cost. In the present empirical analysis to test the hypothesis stated earlier multiple regression model using Ordinary Least Square (OLS) is set. Thus the following type of linear modulation is used:

$$
\begin{gathered}
T Q_{i}=\alpha+\beta_{1} B S_{i}+\beta_{2} D U A_{i}+\beta_{3} A C_{i}+\beta_{4} \log T A_{i}+\mu_{i} \\
T Q_{i}=\alpha+\beta_{1} B S_{i}+\beta_{2} D U A_{i}+\beta_{3} A C_{i}+\beta_{4} \log M C_{i}+\mu_{i} \\
T Q_{i}=\alpha+\beta_{1} B S_{i}+\beta_{2} D U A_{i}+\beta_{3} A C_{i}+\beta_{4} I_{-} B S_{-} D U A_{i}+\mu_{i}
\end{gathered}
$$

And

$$
\begin{aligned}
& \operatorname{ROTA}_{i}=\alpha+\beta_{1} B S_{i}+\beta_{2} D U A_{i}+\beta_{3} A C_{i}+\beta_{4} \log A_{i}+\mu_{i} \\
& \operatorname{ROTA}_{i}=\alpha+\beta_{1} B S_{i}+\beta_{2} D U A_{i}+\beta_{3} A C_{i}+\beta_{4} \log M C_{i}+\mu_{i} \\
& \operatorname{ROTA}_{i}=\alpha+\beta_{1} B S_{i}+\beta_{2} D U A_{i}+\beta_{3} A C_{i}+\beta_{4} I_{-} B S_{-} D U A_{i}+\mu_{i}
\end{aligned}
$$

Where,

$T Q_{i}=$ Tobin's $\mathrm{Q}$ for the period of $\mathrm{i}$.

ROTA $_{i}=$ Retun on Total Assets for the period of $\mathrm{i}$.

$\mathrm{BS}=$ Board Size

DUA $=$ Duality

$\mathrm{AC}=$ Agency Cost

$\log \mathrm{TA}=$ Natural Log of Total Assets

$\operatorname{LogMC}=$ Natural Log of Market Capitalization

I_BS_DUA = Interaction effect of Board size and duality

$\mu_{i}=$ Stochastic Error term for the period of $i$.

\section{Empirical Results}

Descriptive statistics as reported in Table 2 depicts the average board size in GCC Banks as 9.9 directors. This seems to be slightly higher than the optimal board size propounded by Jensen (1993) i.e. seven to eight. Table 2 also shows on average, 87.5 percent of the directors in GCC board structure are independent while 12.5 percent are dependent viz. CEO and Chairman is the same person. It is interesting to note that on anerage 54.16 percent of total sampled GCC banks are controlled by block ownership proxied as agency cost in table 2 .

Table 2. Descriptive statistics of model variables

\begin{tabular}{cccccc}
\hline & B_SIZE & DUALITY & AGENCY_COST & LTA & LMCAP \\
\hline Mean & 9.875000 & 0.125000 & 0.541667 & 8.976909 & 10.47073 \\
Median & 10.00000 & 0.000000 & 1.000000 & 9.189078 & 10.61746 \\
Maximum & 12.00000 & 1.000000 & 1.000000 & 10.51472 & 11.71005 \\
Minimum & 6.000000 & 0.000000 & 0.000000 & 7.074831 & 8.819846 \\
Std. Dev. & 1.261900 & 0.337832 & 0.508977 & 0.843453 & 0.747795 \\
Skewness & -1.485695 & 2.267787 & -0.167248 & -0.353022 & -0.559670 \\
Kurtosis & 5.796095 & 6.142857 & 1.027972 & 2.634462 & 2.812268 \\
N & 24 & 24 & 24 & 24 & 24 \\
\hline
\end{tabular}


We use OLS method to test the hypothesis of Corporate Governance and Value of the Firm (CGVF) model using cross sectional data of 24 GCC banks for the current year of 2013. Table 3 (a) reports results for CGVF model effects using TOBIN's Q as the Explained variable. And the Table 3 (b) portray the effects of corporate governance variables on the return on total assets (ROTA).

As per our first hypothesis GCC bank performance is significantly influenced by the corporate governance variables. It is supported by our regression results, i.e. financial performance proxied by TOBIN's $Q$ in equation1.1 all variables taken together explain 58.3 percent of the cross sectional variation of GCC banks; where as in the case of equation $1.2 \& 1.3$ it is 42.4 and 54.2 respectively. Overall fitness of good as measured by F statistics for equations- 1.1, 1.2 and 1.3 are 99,90 and 95 percent respectively.

To check the robustness of our models we also used the accounting performance proxied by ROTA. In equation-2.2 all variables taken together explain 63.3 percent of the cross sectional variation of GCC banks; where as in the case of equation $2.1 \& 2.3$ it is 36.0 and 38.4 respectively. Overall fitness of good as measured by $F$ statistics for equation- 2.2 and 2.3 are 97 and 95 percent respectively while equation- 2.1 is found to be insignificant and dropped.

As regard to hypothesis-2, i.e. board size positively affect the value/performance of GCC banks. It is found negatively associated with both financial $(\mathrm{t}=2.64, \alpha=.01$ for model-1, $\mathrm{t}=6.06 ; \alpha=.00$ for equation 1.3$)$ and accounting performance ( $t=2.50, \alpha=.05$ for equation-2.1, equation $2.2 \& 2.3$ are found insignificant) thus our findings are similar to the Mashayekhi and Bazaz (2008), Nam et al. (2004), Beasley (1996), Jensen (1993) etc. It indicates that smaller board size will result into the better bank performance. As advocated by Al-Musalli and Ismail (2012), Grove et al. (2011), Kabigting (2011) that smaller board is more capable for monitoring the management closely.

Table 3(a). Estimation results for model-1

\begin{tabular}{cccc}
\hline Tobin's Q & $\begin{array}{c}\text { Equation }-1.1 \\
\text { Coefficients }\end{array}$ & $\begin{array}{c}\text { Equation }-1.2 \\
\text { Coefficients }\end{array}$ & $\begin{array}{c}\text { Equation }-1.3 \\
\text { Coefficients }\end{array}$ \\
\hline INTERCEPT & 0.0467 & 0.1936 & $0.4302^{* *}$ \\
& $(0.1480)$ & $(0.2008)$ & $(0.0709)$ \\
B_SIZE & $-0.0219^{* *}$ & -0.0147 & $-0.0176^{*}$ \\
DUALITY & $(0.0083)$ & $(0.0112)$ & $(0.0076)$ \\
& $0.0855^{* *}$ & $0.0966^{* *}$ & $-1.2193^{*}$ \\
AGENCY_COST & $(0.0284)$ & $(0.0356)$ & $(0.5762)$ \\
& -0.0307 & $-0.0625^{*}$ & $-0.0609^{*}$ \\
LTA & $(0.0283)$ & $(0.0320)$ & $(0.0278)$ \\
& $0.0479^{* *}$ & & - \\
LMCAP & $(0.0164)$ & - & - \\
& - & 0.0208 & $0.1263^{*}$ \\
INTERACTION EFFECT (BOARD_DUAL) & - & $(0.0219)$ & $(0.0543)$ \\
R & - & - & 0.542 \\
R-squared (Adjusted) & 0.583 & 0.424 & 0.359 \\
F-statistic & 0.461 & 0.254 & 2.959 \\
Prob. & 4.763 & 2.499 & 0.04 \\
\hline
\end{tabular}

Note. $(* *)$ and $(*)$ indicates significance level at 0.01 and 0.05 respectively. The values in brackets indicate the Standard Error of Estimates.

Our third hypothesis, i.e. CEO Duality has a negative effect on the performance of GCC Banks. Regression results for equation-1.1 \& 1.2 shows a positive relationship with both financial ( $\mathrm{t}=3.01, \alpha=.01, \mathrm{t}=2.71 ; \alpha=.01$ ) and accounting performance $(\mathrm{t}=3.66, \alpha=.01)$. In addition, we examine how duality interacts with board size. Estimated coefficients of equation- 1.3 with financial performance (Table 3.a) suggest that the dual role of CEO along with optimal board size produces the significant effect on the firm financial performance $(t=2.33, \alpha=.05)$. This is further confirmed by accounting performance coefficients reported in table 3 (b) where $(t=3.16, \alpha=.01)$. Thus the estimated coefficients suggest that board size and the dual role of CEO are likely to improve the GCC Bank performance. 
Table 3(b). Estimation results for model-2

\begin{tabular}{cccc}
\hline ROTA & $\begin{array}{c}\text { Equation -2.1 } \\
\text { Coefficients }\end{array}$ & $\begin{array}{c}\text { Equation }-2.2 \\
\text { Coefficients }\end{array}$ & $\begin{array}{c}\text { Equation }-2.3 \\
\text { Coefficients }\end{array}$ \\
\hline INTERCEPT & 0.0193 & $0.0620^{* *}$ & $0.0325^{* *}$ \\
& $(0.0141)$ & $(0.0148)$ & $(0.0088)$ \\
B_SIZE & $-0.0020^{*}$ & -0.0012 & -0.0017 \\
DUALITY & $(0.0008)$ & $(0.0008)$ & $(0.0009)$ \\
& 0.0044 & $0.0117^{* *}$ & $-0.2057^{* *}$ \\
AGENCY_COST & $(0.0031)$ & $(0.0032)$ & $(0.0664)$ \\
LTA & -0.0030 & -0.0024 & 0.0015 \\
& $(0.0030)$ & $(0.0023)$ & $(0.0025)$ \\
LMCAP & 0.0021 & - & - \\
& $(0.0018)$ & -0.0030 & - \\
INTERACTION EFFECT (BOARD_DUAL) & - & $(0.0017)$ & $0.0196^{* *}$ \\
R & & - & $(0.0062)$ \\
R-squared (Adjusted) & - & 0.384 \\
F-statistic & 0.360 & 0.435 & 0.384 \\
Prob. & 0.105 & 3.202 & 2.965 \\
\hline
\end{tabular}

Note. $(* *)$ and $(*)$ indicates significance level at 0.01 and 0.05 respectively. The values in brackets indicate the Standard Error of Estimates.

The last hypothesis, i.e. Block holders in the ownership structure of GCC banks positively influences the performance. The block holders are proxied by the agency cost. The coefficients are significant at .05 level for financial performance except equation-1.1, where it is negatively insignificant. While in terms of accounting performance it is negatively insignificant except in equation- 2.3 where it is positively insignificant.

\section{Conclusion}

In this study we examined the role of corporate governance variables (board size, duality, agency cost) on performance of selected GCC banks denoted by TOBIN's Q and ROTA. The hypotheses stated were tested on the cross sectional data of 24 GCC banks for the financial year 2012-13. The first finding of our study supports the earlier contention that smaller boards are relatively capable for monitoring the management closely. It is found to be true in GCC banking context. Thus our findings uphold the conclusion of Al-Musalli and Ismail (2012), Grove et al. (2011), Kabigting (2011). On the other hand it contradict with Arouri et al. (2011).

On duality issue our findings conclude that dual role of Chief Executive Officer (CEO) are likely to improve the GCC bank performance. It supports Al-Musalli and Ismail (2012) and contradict with (Arouri et al., 2011), Grove et al. (2011) etc.

The presence of block holders in ownership structure of GCC banks tends to have a positive effect on the financial and accounting performance of banking sector. Therefore it contradicts with Al-Musalli and Ismail (2012), Arouri et al. (2011) and Grove et al. (2011) etc.

In nutshell, the study concludes that the corporate governance poses a significant influence on the financial and accounting performance of GCC banking sector.

\section{Acknowledgements}

Authors would like to extend their gratitude towards the project funded by Deanship of Scientific Research, Salman bin Abdulaziz University, Kingdom of Saudi Arabia.

\section{References}

Abeysekera, I. (2010). The influence of board size on intellectual capital disclosure by Kenyan listed firms. Journal of Intellectual Capital, 11(4), 504-518. http://dx.doi.org/10.1108/14691931011085650

Al-Hawary, S. (2011). The effect of banks governance on banking performance of the Jordanian commercial banks: Tobin's Q model'An applied study'. International Research Journal of Finance and Economics, 71, $35-45$. 
Al-Musalli, M. A. K., \& Ismail, K. N. I. K. (2012). Corporate governance, bank specific characteristics, banking industry characteristics, and Intellectual Capital (IC) performance of banks in Arab Gulf Cooperation Council (GCC) countries. Asian Academy of Management Journal of Accounting \& Finance, 8.

Al-Rashed, W. E. (2010). Corporate performance under corporate governance in the GCC countries. Malaysian Accounting Review, 9, 139-163.

Al Karasneh, I., \& Bolbol, A. (2006). Corporate Governance and Concentration in the Arab Banking Sector and Economic Growth: The Case of the GCC Countries'. Paper presented at the IMF/AMF High-Level Seminar on Institutions and Economic Growth in the Arab Countries.

Arouri, H., Hossain, M., \& Muttakin, M. B. (2011). Ownership Structure, Corporate Governance and Bank Performance: Evidence from GCC Countries. Corporate ownership \& control, 365.

Barako, D., \& Tower, G. (2007). Corporate governance and bank performance: Does ownership matter? Evidence from the Kenyan banking sector. Corporate Ownership and Control, 4(2), 133-144.

Beasley, M. S. (1996). An empirical analysis of the relation between the board of director composition and financial statement fraud. Accounting Review, 443-465.

Bhagat, S., \& Bolton, B. (2008). Corporate governance and firm performance. Journal of Corporate Finance, 14(3), 257-273. http://dx.doi.org/10.1108/14691931011085650

Brown, L. D., \& Caylor, M. L. (2004). Corporate governance study: the correlation between corporate governance and company performance. Corporate Governance Study, Institutional Shareholder Services.

Cadbury, A. (1992). Report of the committee on the financial aspects of corporate governance (Vol. 1). Gee.

Chahine, S. (2007). Activity-based diversification, corporate governance, and the market valuation of commercial banks in the Gulf Commercial Council. Journal of Management \& Governance, 11(4), 353-382. http://dx.doi.org/10.1007/s10997-007-9034-5

Coles, J. L., Daniel, N. D., \& Naveen, L. (2008). Boards: Does one size fit all? Journal of financial economics, 87(2), 329-356. http://dx.doi.org/10.1016/j.jfineco.2006.08.008

Dalton, C. M., \& Dalton, D. R. (2005). Boards of directors: Utilizing empirical evidence in developing practical prescriptions. British Journal of Management, 16(s1), S91-S97.

Fallatah, Y., \& Dickins, D. (2012). Corporate governance and firm performance and value in Saudi Arabia. African Journal of Business Management, 6(36), 10025-10034.

Grove, H., Patelli, L., Victoravich, L. M., \& Xu, P. T. (2011). Corporate governance and performance in the wake of the financial crisis: Evidence from US commercial banks. Corporate Governance: An International Review, 19(5), 418-436. http://dx.doi.org/10.1111/j.1467-8683.2011.00882.x

Hartzell, J. C., \& Starks, L. T. (2003). Institutional investors and executive compensation. The journal of finance, 58(6), 2351-2374. http://dx.doi.org/10.1046/j.1540-6261.2003.00608.x

Heracleous, L. (2001). What is the impact of corporate governance on organisational performance? Corporate Governance: An International Review, 9(3), 165-173. http://dx.doi.org/10.1111/1467-8683.00244

Hermalin, B. E., \& Weisbach, M. S. (1991). The effects of board composition and direct incentives on firm performance. Financial management, 101-112. http://dx.doi.org/10.2307/3665716

Jensen, M. C. (1993). The modern industrial revolution, exit, and the failure of internal control systems. The journal of finance, 48(3), 831-880. http://dx.doi.org/10.1111/j.1540-6261.1993.tb04022.x

Jensen, M. C., \& Meckling, W. H. (1976). Theory of the firm: Managerial behavior, agency costs and ownership structure. Journal of financial economics, 3(4), 305-360. http://dx.doi.org/10.1016/0304-405X(76)90026-X

Kabigting, L. C. (2011). Corporate governance among banks listed in the philippine stock exchange. Journal of International Business Research, 10(Special Issue).

Kang, E., \& Zardkoohi, A. (2005). Board leadership structure and firm performance. Corporate Governance: An International Review, 13(6), 785-799. http://dx.doi.org/10.1111/j.1467-8683.2005.00470.x

Kapopoulos, P., \& Lazaretou, S. (2007). Corporate ownership structure and firm performance: evidence from Greek firms. Corporate Governance: An International Review, 15(2), 144-158.

Larcker, D. F., Richardson, S. A., \& Tuna, I. (2007). Corporate Governance, Accounting Outcomes, and Organizational Performance. The Accounting Review, 82(4), 963-1008. 
Leech, D., \& Leahy, J. (1991). Ownership structure, control type classifications and the performance of large British companies. Economic Journal, 101(409), 1418-1437.

Mashayekhi, B., \& Bazaz, M. S. (2008). Corporate Governance and Firm Performance in Iran. Journal of Contemporary Accounting \& Economics, 4(2), 156-172. http://dx.doi.org/10.1016/S1815-5669(10)70033-3

Nam, S.-W., Nam, I.-C., \& Ong. (2004). Corporate governance in Asia. Asian Development Bank Institute.

Ongore, V. O. (2011). The relationship between ownership structure and firm performance: An empirical analysis of listed companies in Kenya. African Journal of Business Management, 5(6), 2120-2128.

Rashid, K., \& Islam, S. M. (2013). Corporate governance, complementarities and the value of a firm in an emerging market: the effect of market imperfections. Corporate Governance, 13(1), 70-87.

Saidi, N. (2011). Corporate governance in the GCC: What has been done and what remains. Qatar Business Review Magazine.

Shleifer, A., \& Vishny, R. W. (1997). A survey of corporate governance. The journal of finance, 52(2), 737-783. http://dx.doi.org/10.1111/j.1540-6261.1997.tb04820.x

Smith, M. P. (1996). Shareholder activism by institutional investors: Evidence from CalPERS. The journal of finance, 51(1), 227-252. http://dx.doi.org/10.1111/j.1540-6261.1996.tb05208.x

Sufian, F. (2010). Does foreign presence foster Islamic banks' performance? Empirical evidence from Malaysia. Journal of Islamic Accounting and Business Research, 1(2), 128-147. http://dx.doi.org/10.1108/175908 11011086723

Tandelilin, E., Kaaro, H., \& Mahadwartha, P. A. (2007). Corporate governance, risk management and bank performance: Does type of ownership matter. EADN individual research grant project, (34).

\section{Copyrights}

Copyright for this article is retained by the author(s), with first publication rights granted to the journal.

This is an open-access article distributed under the terms and conditions of the Creative Commons Attribution license (http://creativecommons.org/licenses/by/3.0/). 